\title{
ВЛИЯНИЕ МУЛЬТИКУЛЬТУРАЛИЗМА НА СИСТЕМУ УПРАВЛЕНИЯ И ДЕЛОВОГО ОБЩЕНИЯ БИЗНЕСА ХУАЦЯО ЮГО-ВОСТОЧНОЙ АЗИИ И ОКЕАНИИ В НАЧАЛЕ ХХІ ВЕКА
}

THE INFLUENCE OF MULTICULTURALISM ON THE MANAGEMENT SYSTEM AND BUSINESS COMMUNICATION OF HUAQIAO BUSINESS IN SOUTHEAST ASIA AND OCEANIA AT THE BEGINNING OF THE 21ST CENTURY

Ya. Zakhariev

Summary: The article describes the specificity of the influence of multiculturalism on the management system and corporate governance of the Huaqiao business in Southeast Asia and the South Pacific region in 2000-2020. The key elements of influence are shown and the question of the synthesis of cultural elements in order to increase the efficiency of management for the big business of the national minority is touched upon.

Keywords: multiculturalism, multiculturalism and Huaqiao, Huaqiao Southeast Asia, the Chinese community of Southeast Asia, Southeast Asia, Oceania, the South Pacific, UTR, China, Chinese business, Chinese business circles, corporate culture, customary law, Chinese customary law, the Chinese community, the Chinese community of Southeast Asia, the Huaqiao of Southeast Asia, Australia and Oceania.

\author{
Захарьев Ярослав Олегович \\ эксперт, МГИМО(У)МИДРФ \\ sbkmsh@mail.ru
}

Аннотация: В статье изложена специфика влияния мультикультурализма на систему управления и корпоративное управления бизнеса хуацяо ЮгоВосточной Азии и Южно-Тихоокеанского региона в 2000-2020 гг. Показаны ключевые элементы влияния и затронут вопрос синтеза элементов культуры с целью повышения эффективности управления для крупного бизнеса национального меньшинства.

Ключевые слова: мультикультурализм, мультикультурализм и хуацяо, хуацяо ЮВА, китайская община Юго-Восточной Азии, Юго-Восточная Азия, Океания, Южно-Тихоокеанский регион, ЮТР, КНР, китайский бизнес, китайские деловые круги, корпоративная культура, обычное право, китайское обычное право, китайская община, китайская община Юго-Восточной Азии, хуацяо Юго-Восточной Азии, Австралия и Океания.
$\mathrm{B}$ 2000-2020 гг. XX1 века под влиянием процессов глобализации и обострения тенденций к регионализации в мире системы управления крупным бизнесом подвергается комплексным воздействиям, порожденных волнами локальных и глобального экономических кризисов, изменениями в геостратегической конъюнктуре рынка, инновационными технологиями и сменой поколений руководящего звена холдингов и отраслевых компаний.

Бизнес хуацяо Юго-Восточной Азии представляет собой комплекс, часто образующий целые отрасли. Например, банковская система Сингапура, Таиланда, Индонезии, Лаоса, Филиппин и Камбоджи, крупный игрок в СРВ, Малайзии, Тимор-Лешти.

Любая деловая активность, которую проводили китайцы в Юго-Восточной Азии, учитывала специфику региональной и национальной конъюнктуры рынка каждой страны ЮВА и Южно-Тихоокеанского региона (ЮТР) с целью успешной экспансии и закрепления в нише на длительное время [1-30]. Происходила синтезированное внедрение элементов управления, взаимодействия с деловыми партнерами других национальных элит, языковое (развивались как диалекты китайского языка в каждой местности, так и языки национального большинства, с частичной консервацией оборотов деловой культуры и герменевтической среды). Китайская культура делового общения позволяла деловым кругам производить не слепое копирования, которое ведет всегда к краху, а брать лишь адаптированные под необходимость качественные элементы для развития дела в странах пребывания китайских капиталов, китайской рабочей силы и китайского национального меньшинства. В разных странах три данных фактора были изменчивы, как и политико-экономическая ситуация в странах, нуждавшихся в китайцах в разных сегментах ниш. В Юго-Восточной Азии, большая часть которой была колониями европейских стран преобладали нормативные тенденции, закрепленные в законодательствах метрополий, что заставляло китайский бизнес вести легальную деятельность в рамках англо-саксонской и континентальной правовой 
системы, однако обычное право хуацяо, в тех пластах оборота, где контроль права над экономической деятельностью не требовался, развивалось по видам обычая, характерного в материковом Китае со спецификой у выходцев каждой конкретной провинции. Часто в колониальный период китайские бизнесмены в ЮВА и ЮТР не сколько кооперировались, сколько конфликтовали именно в сегменте делового оборота обычного права и лингвистического барьера между диалектами разных провинций, откуда были выходцами те или иные бизнесмены. Приблизительно к 1950м гг. XX века образовалась более устойчивая прослойка диалектов китайского языка, которые использовали массово китайцы-бизнесмены ЮВА и ЮТР для упрощения понимания. Контрактное право в сегменте крупных сделок шло в это время на трех языках с обязательным вариантом европейского языка метрополии. Исключение составлял Таиланд, в котором третьим языком выступали тайский, французский (реже, приграничные с Лаосом) или английский.

После обретения независимости и того, что ряд стран пошли по социалистической модели развития произошел дополнительный стимул унификации делового оборота и языка общения внутри китайского бизнеса в ЮВА и ЮТР. Так наньминьхуа и кантонского вытеснили фуцзяньхуа и стали ведущими диалектами в системе делового внутреннего общения. Также они позволяли создать барьер для китайцев-выходцев из северных провинций, безуспешно пытавшихся получить некоторые ниши в периоды нестабильности и бегства капиталов из Китая и Тайваня в 1940-1970-х гг.

Другой особенностью влияния мультикультурализма на корпорации стал переход маркетинговой стратегии на нового целевого пользователя- национальное большинство той или иной страны в контексте производства товаров и услуг, актуальных тех или иным этносам, социальным группам, политикам, военным и иным гражданам данных стран некитайского происхождения [1-13]. Одной из ярчайших стратегий здесь можно отметить бизнес и выборную стратегию Таксина Чиннавата и его сестры-преемницы Йинглак на посту директоров семейной корпорации и в качестве премьер-министров. Здесь лозунг, ориентированный на тайцев несколько напугал даже китайские круги спонсоров, сокративших финансирование их предвыборных компаний, что привело к сокращению массы средств и потери влияния во время предвыборных компаний, роста социальной напряженности и усиления военных (тайцев).

Другой любопытной тенденцией мультикультурного влияния является пересмотр менеджмента системы управления руководящего звена с принципа родства до Азиатского кризиса 1997 года, к принципу найма компетентного штата управленцев, выведенного и не входившего в состав советов директоров, но выступающего как класс наёмных высокооплачиваемых рабочих на период их антикризисной стратегии сроком контрактов на 1.5-3 года с возможным продлением и, или досрочным расторжением. Другими словами, ответственность перешла к компетентным специалистам, не способных отодвинуть советы директоров и их наследников от власти, но при этом компании быстро вышли из тяжелых последствий кризиса [10-13].

В начале XX1 века с усилением роли КНP на мировой арене бизнес из материкового Китая стал активно участвовать в серии проектов ЮТР [3] и ЮВА [10-30], часто вытесняя компании хуацяо из ниш. Несмотря на это ведущая роль путунхуа, как системного образующего диалекта в контексте языка делового общения между китайскими деловыми кругами ЮВА, КНР и ЮТР не обозначилась ярко. Причиной этому является серия факторов, связывающих деловые элиты китайского происхождения именно через южные диалекты китайского языка. Ряд ниш, которые планировал занять китайский бизнес КНР в ЮТР и ЮВА просто оказался занят, а население приняло в штыки все инициативы в т.ч. после солидных взяток из Пекина по усилению интеграции и созданию новых проектов с участием китайских компаний из КНР. Разумеется, корпоративная культура бизнеса КНР, ЮВА и ЮТР [3,10-30] имеет существенные отличия, как по правовому полю страны-резидента, так и по эволюции регионального обычного права в каждом регионе и нише конкретного производства и сферы услуг. Здесь обозримый синтез унификации делового общения, под влиянием региональных тенденций, волн глобального экономического кризиса формируется активно и обладает спецификой каждого поля и ниши присутствия [10-30].

Влияние коронавируса в контексте усиления центробежных тенденций в рамках складывающегося комплексного партнерства китайского бизнеса КНР, ЮВА и ЮТР не наблюдается. Более того, рост интернет- торговли, логистики, новых форм в рамках FOB и CIF только способствовали дополнительному развитию договорного права. Специфика заключается в том, что переговоры все чаще проходят через видеоконференции, и рост редакционных правок проходит не на встречах, а при чтении сторонами условий контрактов. Следует отметить, что ввиду развитого бизнеса хуацяо с другими регионами, в т.ч. логистики с т.з. программного обеспечения и софтов бизнес не понес расходы по конверсии сегмента отделов внешних связей, ввиду наличия полностью готовой в 2000-2018 гг. инфраструктуры к дистанционным формам делового общения, в отличие от ряда развивающихся стран в других частях мира. Например, бизнес итальянской общины в США.

Некоторые источники по-прежнему указывают на особенности влияния курса КНР на развитие деловой активности хуацяо ЮВА и изменений, происходящих во 


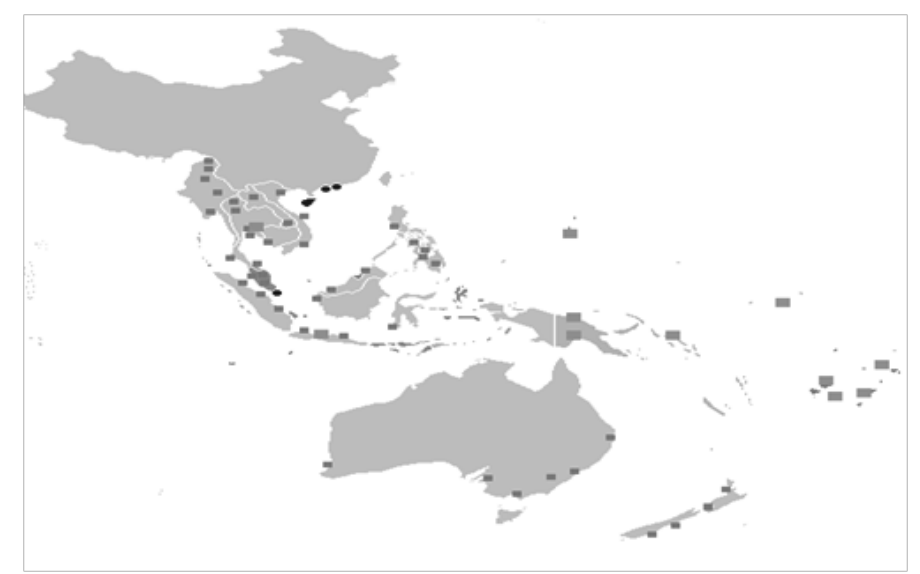

Карта распространения китайского языка и его применяемых на пространстве диалектов в населенных пунктах государств Юго-Восточной Азии, Южно-Тихоокеанского Региона и КНР. Точками отмечены регионы концентрации китайских капиталов и ареалов среды делового общения на китайском языке в контексте завяленных в статье вопросов регионального взаимодействия.

время пандемии КОВИД-19 в регионах за период конца 2019- начала 2021 гг. [32-33] При этом особо следует подчеркнуть, что хуацяо остаются самодостаточной политической и национальной единицей, которая в форме комплекса мер экономических, социальных, политических и стратегических продолжает бороться за влияние в регионе ЮВА, а также ведет экспансию в Океанию.[1-33]

Интернет, как глобальная унифицирующая инстанция общения всех народов и социальных страт также внес свой вклад в особенность делового общения хуацяо. В этом поле у хуацяо Юго-Восточной Азии есть свои онлайн издания, газеты, групповые чаты, сайты для деловой активности, платформы банковских операций с адаптированными серверами под конкретные языки и диалекты, в случае с особыми клиентами им дается онлайн консультант и переводчик с диалектов, имеются и отдельные опции в рамках учета обычаев тех или иных групп китайских бизнесменов, начиная с аудитории и атмосферной среды, где будут проходить деловые переговоры, до предложения подробного сценария с логистикой и этапами сделок с виртуальными турами разного объема предложений, начиная с обложки видео-окон для онлайн-бесед и заканчивая прогулками в виртуальной реальности по отелям или бизнес-центрам, где уже будет идти личная встреча. Не обходится тут и без услуг кибер-безопасности с подробными пакетами, и учений (виртуальных и реальных) в случае стихийных бедствий, атак террористов, распространения инфекций в контексте биологического терроризма: как себя вести и какие меры предпринять рассказывает онлайн-консультант, либо сам руководитель службы безопасности.

Конфликты при неисполнении сторонами обяза- тельств теперь также чаще разрешаются не через встречи, а по средствам обращения участников в суды, прописанных в договорах предметной юрисдикции, что экономит время и побуждает к более ответственному исполнению обязанностей сторон. В контексте переговоров при барьере между носителями диалектов китайского языка, по-прежнему востребован институт переводчиков-секретарей, интернет-программы, ридеры на третьем языке договора, иероглифические уточнения через программы рукописного ввода иероглифов при недопонимании конкретного символа сторонами, использующих полное и упрощенное китайское письмо.

Помимо этого, в Юго-Восточной Азии и Океании активно используют английский язык в системе делового общения. Его также в последние 20 лет активно внедряют в оборот и производители из КНР. Усиление его роли в рамках взаимодействия бизнес-партнеров КНР, ЮТР и Океании очевидно, а актуальность не вызывает никаких сомнений.

Таким образом, следует отметить, что мультикультурализм сыграл особую позитивную роль в рамках развития деловой активности китайцев в Юго-Восточной Азии, Океании и КНР, благодаря тому, что китайцы умело проводили синтез актуальных элементов без слепого копирования готовых моделей, что позволило бизнесу обрести витальные стратегии развития, оперативно изменяться под влиянием геостратегической региональной и глобальной конъюнктуры рынка в рамках конкуренции за актуальные ниши в том или ином государстве ЮВА и ЮТР в начале XX1 века, при этом сохраняя свою идентичность [31] и самостоятельность под влиянием новых вызовов. 


\section{ЛИТЕРАТУРА}

1. $А B C$ Radio Australia [Электронный радио-ресурс]. - Режим доступа: radioaustralia.net.au/international/2012-06-01/china-a-better-pacific-friend-than-ussamoan-pm/953518.

2. Callick R. Looters shot dead amid chaos of Papua New Guinea's anti-Chinese riots [Электронный ресурс]. - Режим доступа: theaustralian.com.au/news/lootersshot-dead-amid-chaos-of-papua-new-guinea-anti-chinese-riots/story-e6frgno-1225715006615.

3. Cholevski D. The People's Republic of China's Aid Program in Oceania 2005-2009 // University of Lodz. - 2013.

4. Hanson F. China: stumbling though the Pacific: The new banker in Town // Lowy Institute for International Policy. - 2011.

5. James Chin. Papua New Guinea in 2009: Anti-Chinese Rioting and the Liquefied Natural Gas Deal // Asian Survey. - 2010. - Vol. 50. - № 1. - Pp. $247-252$.

6. Xinhua // China daily 27.03.2008 [Электрон-ный ресурс]. - Режим доступасhinadaily.cn/china/2008/03/27content_6568524.htm.

7. Дарбалаева Д.А., Цыренжапов У.В., Бешенцев А.Н., Дагданова С.Ж. Система мониторинга и анализ особенностей социально-экономического развития трансграничных территорий России, Монголии и Китая // Научное обозрение. - 2012. - № 6. - С. 580-589.

8. Котилко В.В. Программы регионального развития приграничных регионов Китая // Научное обозрение. - 2013. - № 1. - С. 306-313.

9. Веремеенко Е.Г. Применение инновационных технологий в работе крупнейших портов мира // Научное обозрение. - 2013. - № 9. - С. 365-367.

10. Faizal Bin Yahya Singapore in 2010: rebounding from economic slump, managing tensions. / Edited by Daljit Singh. - Southeast Asian Affairs, 2010. - 257-270 p.

11. Manu Bhaskaran Challenges facing the Singapore economy. / Edited by Daljit Singh. - Southeast Asian Affairs, 2014. - 290-304 p.

12. Edited by Daljit Singh. - Southeast Asian Affairs, ISEAS. Singapore. 2000.

13. Edited by Daljit Singh. - Southeast Asian Affairs, ISEAS. Singapore. 2001.

14. Edited by Daljit Singh. - Southeast Asian Affairs, ISEAS. Singapore. 2002.

15. Edited by Daljit Singh. - Southeast Asian Affairs, ISEAS. Singapore. 2003.

16. Edited by Daljit Singh. - Southeast Asian Affairs, ISEAS. Singapore. 2004.

17. Edited by Daljit Singh. - Southeast Asian Affairs, ISEAS. Singapore. 2005.

18. Edited by Daljit Singh. - Southeast Asian Affairs, ISEAS. Singapore. 2006.

19. Edited by Daljit Singh. - Southeast Asian Affairs, ISEAS. Singapore. 2007.

20. Edited by Daljit Singh. - Southeast Asian Affairs, ISEAS. Singapore. 2008.

21. Edited by Daljit Singh. - Southeast Asian Affairs, ISEAS. Singapore. 2009.

22. Edited by Daljit Singh. - Southeast Asian Affairs, ISEAS. Singapore. 2010.

23. Edited by Daljit Singh. - Southeast Asian Affairs, ISEAS. Singapore. 2011.

24. Edited by Daljit Singh. - Southeast Asian Affairs, ISEAS. Singapore. 2012.

25. Edited by Daljit Singh. - Southeast Asian Affairs, ISEAS. Singapore. 2013.

26. Edited by Daljit Singh. - Southeast Asian Affairs, ISEAS. Singapore. 2014.

27. Edited by Daljit Singh. - Southeast Asian Affairs, ISEAS. Singapore. 2015.

28. Edited by Daljit Singh. - Southeast Asian Affairs, ISEAS. Singapore. 2016.

29. Edited by Daljit Singh. - Southeast Asian Affairs, ISEAS. Singapore. 2017.

30. Edited by Daljit Singh. - Southeast Asian Affairs, ISEAS. Singapore. 2018.

31. Edited by Daljit Singh. - Southeast Asian Affairs, ISEAS. Singapore. 2019.

32. Прожогина С.В. Новые Идентичности. М. МБА. 2012. -С. 28-146.

33. https://asiasociety.org/policy-institute/southeast-asia-and-covid-1924.03.2021.

34. https://thediplomat.com/2021/02/is-chinas-covid-19-diplomacy-working-in-southeast-asia/ 24.03.2021.

() Захарьев Ярослав Олегович (sbkmsh@mail.ru). 